\title{
Activation of investment attraction in the dairy sub-complex of the agro-industrial complex on the basis of public-private partnership
}

\author{
Galina Demishkevich ${ }^{1, *}$, Aleksey Petrov ${ }^{2}$, and Lyudmila Botasheva $^{3}$ \\ ${ }^{1}$ Russian Academy of Personnel Support for the Agroindustrial Complex, 111621, Orenburgskaya \\ str., 15b, Moscow, Russia \\ ${ }^{2}$ Ulyanovsk State Agricultural Academy named after P. A. Stolypin, 432000, Novuy Venets Blvd., 1, \\ Ulyanovsk, Russia \\ ${ }^{3}$ Financial University under the Government of the Russian Federation (Financial University),125993, \\ Leningradskiy ave., 49, Moscow, Russia
}

\begin{abstract}
Today, the dairy sub-complex of the Russian agro-industrial complex (AIC) faces the task of increasing volumes and production efficiency to ensure import substitution for milk and dairy products. A shortage of their own investment resources for the expansion or technical re-equipment of production is the problem of many milk producers. The solution can be found in attracting private investments into the industry using public-private partnership (PPP) mechanisms. The purpose of the study is to develop an organizational and economic mechanism to attract investment in the dairy sub-complex of the AIC on the basis of PPP. For this purpose, theoretical aspects of the use of the PPP mechanism in Russia and abroad, as well as experience in implementing investment projects in the second sphere of Russia's dairy sub-complex, have been studied. The paper presents a scheme for attracting investments in agriculture (using the example of dairy cattle breeding) on the principles of PPP. The key participants in PPP are state authorities, agricultural commodity producers and private investors. The proposed scheme is aimed at reducing risks in the implementation of the project that can give it additional attractiveness. The calculation, executed on the basis of analysis of actual data of agricultural organizations in the Ulyanovsk region, shows a sufficient level of efficiency of investment in the dairy production.
\end{abstract}

\section{Introduction}

The dairy sub-complex of the AIC of Russia faces the problem of the expansion of production and import substitution of products that requires introduction of modern innovative technologies. This is especially true for the second sphere of the dairy subcomplex, that is, for dairy cattle breeding, since without the development of a raw material base, it is impossible to increase the production of dairy products.

Obsolescence of material and technical base and a significant decrease in the genetic potential of cows is a big issue for many agricultural producers producing milk. The situation can be rectified by a comprehensive reorganization of the dairy cattle breeding

* Corresponding author: galina-demis@ mail.ru 
technology that includes the replacement of equipment, the modernization of cattlebreeding premises (or the construction of new ones), the purchase of thoroughbred cattle for replacement or expansion of livestock. This requires large investments for a long time. Most agricultural producers do not have their own investment resources, and there are no opportunities to attract them. They need large investments for a long time, especially when organizing production using modern high-performance equipment. The use of public funds (both regional and federal) for direct financing of investment in production cannot be considered expedient for two reasons. Firstly, there will be problems with their distribution, and secondly, an effective mechanism to control the use of public funds has not yet been created. Therefore, it is necessary to attract private capital from other industries and regions, and foreign investment. It can be implemented on the principles of public-private partnership (PPP).

\section{Concepts}

PPP should be understood as a set of schemes, principles and mechanisms of economic relations, in which state and private entrepreneur structures operate within the framework of a contract for the implementation of innovative projects (Makhortov \& Semchenkov, 2007). PPP can include any economic or legal relations between government bodies on the one hand, and private entities on another hand, with the exception of contractual relations on the state order (Delmon, 2010).

In the innovative development of the dairy sub-complex of the agro-industrial complex in Russia, in most cases the leading role is played by the state (that often acts as the initiator), and it will be more accurate to talk about public-private partnership. The term private-public partnership is also not devoid of correctness, if a private partner plays a leading role in such a partnership (Kozlov \& Letov, 2012; Kuznetsov, 2010; Plotnikov, 2011).

The global experience offers several basic financing schemes for projects based on the PPP approach (Makhortov \& Semchenkov, 2007; Plotnikov, 2011; Kvasov, 2010; Kubasova, 2009; Kulikov, 2012; Sycheva; 2010; Sychev \& Sycheva; 2013; A new approach to public-private partnerships, 2012; Lawson, 2013), such as:

1. BOT (Build-Operate-Transfer);

2. BOOT (Build-Own-Operate-Transfer), similar to the BOT model.

3. BTO (Build-Transfer-Operate). State bodies pay for the construction of the facility when it is transferred or before it. Payment for construction is made separately from the payment for exploitation.

4. BOO (Build-Own-Operate). A private organization builds, owns and manages the project, as in the case of the BOT model, but without the subsequent transfer of the object to the state.

5. BOR (Build-Operate-Renewal of concession), similar to the BOO model.

6. BOOS (Build-Own-Operate-Sell). Similarly to BOT, but government agencies pay the project company the residual value of the project when it is transferred.

7. BOOST (Build-Own-Operate-Subsidize-Transfer), similar to the BOT model.

8. BRT (Build-Rent-Transfer), similar to the BOT model.

9. BT (Build-Transfer) - a project company builds the object and passes it to the state.

10. BOLB - (Buy, Own, Lease Back) - a private investor builds or buys an object, sells it to the state structures with a condition to get it on lease and conduct economic activity (Kulov, 2011).

11. DBFO (Design-Build-Finance-Operate). The state retains the rights to the created object and leases it to the project company for the concession period (similar to the BOO model). 
12. DCMF (Design-Construct-Manage-Finance), similar to the BOO model.

13. ROO (Rehabilitate-Own-Operate), similar to the BOO model.

14. ROT (Rehabilitate-Operate-Transfer), similar to the BOT model.

15. Alzira - a private investor builds a social or engineering infrastructure, conducts economic activities and concludes a state contract for the provision of services to a certain group of population (Kulov, 2011).

In the "Big Seven", England succeeded in the construction of objects with the help of PPP. In developing countries, these are Mexico and Chile (Brusser and Rozhkova, 2007).

According to the Chamber of Commerce and Industry of the Russian Federation, the main features of economic relations within the PPP are the following:

- A sufficiently long period of the contract;

- Co-investment of public authorities and private business;

- Division of possible risks between public authorities and private business;

- Property objects or socially important services become the subject of an agreement between authorities and private business when it is necessary to build, reconstruct or modernize a property object;

- Business takes part in the construction, reconstruction or modernization of the object of the contract, as well as in its subsequent operation and maintenance.

The forms of PPP, the application of which will give the greatest economic effect, largely depend on the scope of application, and they will be very different in efficiency in the social sphere, education or dairy sub-complex (Kvasov, 2010; Kulikov, 2012; Piliakina, 2010).

\section{Data and methodology}

The works of domestic and foreign scientists and practitioners, and legislative and regulatory acts of the Russian Federation on the development of public-private partnership became the theoretical and methodological basis of this study. The issues of public-private partnership were considered in the works of V.G. Varnavsky, D.N. Efremov, I.N. Kvasov, A.Ya. Porovskaia, and I.S. Sandu.

Such methods as monographic, computational-constructive, comparative, economicstatistical and others were applied.

The introduction of PPP for the innovative development of a dairy sub-complex promises a number of advantages for both government agencies and private businesses. Among the benefits that the public sector will receive are the following (Porovskaia, 2009, Porovskaia, 2008):

1. Modernization and innovation of municipal and state structures.

2. Active participation of the state in strategic planning of private business.

3. Decrease in the future budget expenditures and increase in revenues from the use of state property, and growth in tax revenues.

4. Positive synergistic effect from joint activities with business.

5. The division of risks arising in the process of project implementation with private business.

6. Increasing level of competition in the provision of public services.

7. Application of business experience in decision-making and techniques to increase labor productivity in government structures.

8. Increasing the attractiveness for potential investors of regions or industries within which PPP mechanisms are implemented.

Along with the advantages, state structures when participating in PPPs, face a number of significant shortcomings:

1. Insufficient level of state participation in project management. 
2. If the private partner decides to stop financing the project, the money invested by the state structures in the development of industrial and social infrastructure will not be returned.

3. Imperfection of legislation. There is no federal law on public-private partnership that clearly defines the rights and obligations of the parties of PPPs.

4. The emergence of additional risks in the implementation of the project, due to the participation of private businesses. There is a need for careful selection of a private partner. Clearly defined criteria for choosing a private partner to participate in the project based on PPP are needed.

5. Increasing time for the decision-making process due to the need to coordinate management decisions with the private partner.

With the participation in the implementation of the PPP project, the private business benefits in the following way (Porovskaia, 2009, Porovskaia, 2008):

1. Increasing availability of various sectors of the region's economy for private businesses. Increasing attractiveness of sectors and territories previously estimated as unnecessarily risky for investment.

2. The possibility of participation of representatives of private business in the coordination of plans for the development of the dairy sub-complex of the region.

3. The possibility of using state assets and obtaining additional profits from their use.

4. Increase in investment resources in the implementation of the project at the expense of budgetary funds.

5. Reducing risks in the implementation of the project through the participation of government agencies.

6. Expanding opportunities for development at the expense of construction or modernization of industrial, transport and social infrastructure financed by government agencies.

7. Improving image of business among consumers.

Along with the advantages, private business in the implementation of the project on the basis of PPP faces a number of difficulties:

1. The implementation of its own project from the planning stage is made dependent on the plans and capabilities of public authorities, and the schedule for their part of the project implementation.

2. Impossibility of authoritarian project management in connection with the need to coordinate management decisions with state structures.

3. The possibility of having an additional control over the implementation of the project can scare off a part of private investors, as it deprives them of a part of their independence.

One of the reasons that hinder the development of economic relations in the dairy subcomplex in Russia based on the principles and mechanisms of PPP is the imperfection of the legislative and legal framework that would clearly define the principles of PPP development. Legislative acts regulating the economic relations of the entities are to be adopted with the participation of business representatives in drafting these acts (Ziatkov, 2008). In this respect, an example of the developed European countries, such as Germany, is indicative where representatives of unions and business associations take a direct part in the discussion of projects, laws, and can lobby the interests of their members in the state structures (Kholodnaia, 2009).

Today, economic relations within the framework of PPPs are regulated by several laws and legal acts of the Russian Federation.

The Federal Law No. 225-FZ of December 30, 1995 (as amended on 19.07.2011) "On Production Sharing Agreements" (Kulov, 2011; Ziatkov, 2008), unfortunately, determines only the legal basis for the relations arising in the process of making investments in prospecting, exploration and mining of mineral raw materials in the Russian Federation, on 
the continental shelf and (or) within the exclusive economic zone of the Russian Federation on the basis of production sharing agreements.

The Federal Law No. 117-FZ of 21.07.2005 (as amended on December 28, 2013) "On Concession Agreements" regulates relations arising between the parties of the concession agreement related to the preparation, conclusion, execution and termination of concession agreements, establishes guarantees of rights and legitimate interests of these parties (Brusser \& Rozhkova, 2007).

The Federal Law No. 44-FZ of 05.04.2013 (as amended on December 28, 2013) "On the contract system in the sphere of procurement of goods, works, services to ensure state and municipal needs" regulates relations arising in the provision of state and municipal needs (Chamber of Industry and Commerce of the Russian Federation).

The Federal Law No. 156-FZ of November 29, 2001 (as amended on July 23, 2013) “On Investment Funds" (Piliakina, 2010). Under this Law, it is possible to create PPP based on the organization of closed-end public mutual funds of real estate with trust management of the state property by private companies (Porovskaia, 2009).

All laws regulating relations within the framework of PPP are to a very small extent applicable for the development of the dairy sub-complex. The reason is that they were written at a time when the main attention of the state, including the legislature, was focused on more important industries for the state (for example, fuel and energy companies).

The PPP mechanism, which is actively used in foreign countries, is a life-cycle contract (LCF) or DBFO (Zusman \& Arakelyan, 2010). On the principles of PPP, the project goes through all stages of implementation. Under the terms of the contract, the private partner carries out design, construction, financing, and management. State structures are obliged to finance the project as grantors and provide land plots necessary for the implementation of the project. Also, state structures can provide guarantees for financing part of the project (Sandu \& Ryzhenkova, 2015).

The use of this mechanism of PPP in the agro-industrial complex makes it possible to increase the investment attractiveness of the project. Provision a land plot from regional or federal reserves as an alternative to buying it into ownership reduces the cost of long-term expenditures, increasing the project payback. This is also facilitated by obtaining a state grant for the implementation of the project. The interest of the state will be in raising tax revenues and creating new jobs in the future (Ushachev, 2014).

If we apply this experience to the dairy sub-complex of the agro-industrial complex, then a company or a consortium of companies that performs all the work on the fulfillment of the life cycle contract, i.e. the construction, production or supply of agricultural machinery products, its servicing can become a private partner in the implementation of innovative projects. Participating in the project, they expand their sales market for their products and services on the production, which are created through the use of the PPP mechanisms. At the same time, another private partner, an agricultural commodity producer (an agricultural organization, or a peasant farm), is in charge of the PPP production management phase.

\section{Results}

Based on the foregoing theoretical research and analysis of the practical implementation of projects for the creation, expansion or modernization of production in the dairy subcomplex, we propose a model for the implementation of an investment project based on public-private partnership (PPP) in the dairy sub-complex of the agro-industrial complex (the calculation of efficiency was executed on the materials of the Ulyanovsk region) (Petrov, 2015). This model provides for the implementation of the project on the basis of existing agricultural production with the involvement of public funds and the means of an 
outside investor. The scheme of the project organization for the establishment (expansion) of a dairy farm on the basis of public-private partnership is shown on the Figure 1.

The key parties of PPP in this case are the state authorities, the agricultural commodity producer, on the base of which the project will be implemented, and the private investor. The remaining participants of this scheme are a credit organization, a leasing company, a scientific institution and a processing enterprise. They participate in the implementation of the project on a contractual basis in the form of carrying out their core activities (providing services, supplying equipment, and ensuring the sale of products).

The main interest of the investor is its intention to get profit from the capital invested in the project, with the amount exceeding the refinancing rate and the average level of profitability in the economy (to compensate for the risk of investing in a new direction). The investor does not become the owner of the agricultural organization. It retains economic independence, and its members (shareholders) have their previous share of the organization's capital.

The interest of the agricultural organization is to obtain a part of the profit for the duration of the project implementation and to receive in the ownership, at the end of the project, an established efficient production with the use of progressive technologies.

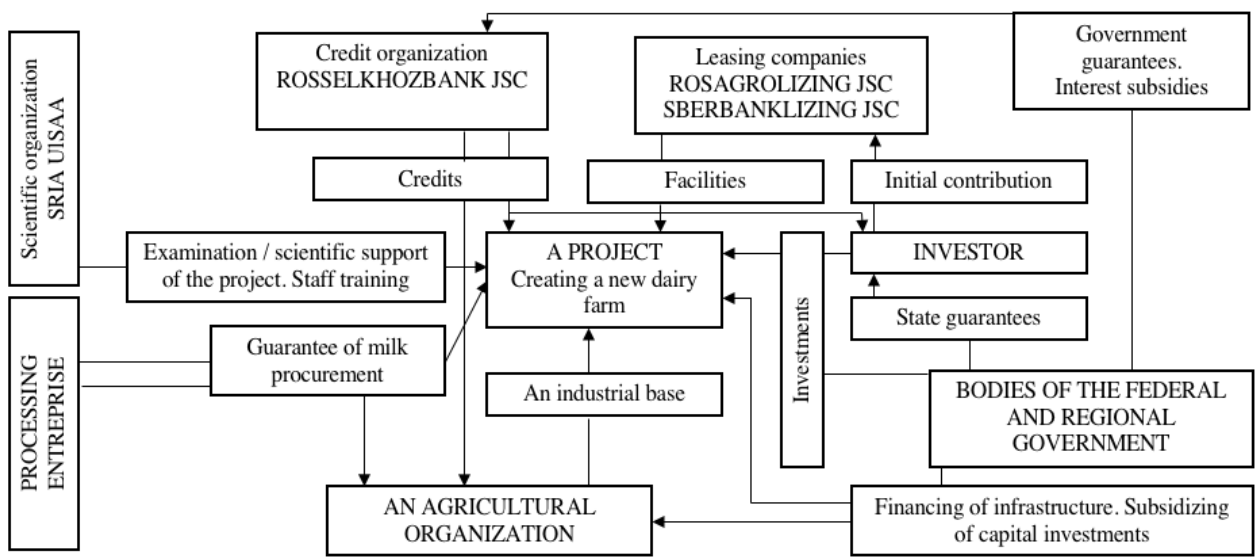

Fig. 1. Scheme of the organizational and economic mechanism for attracting business to the development of the dairy sub-complex of the agro-industrial complex on the principles of publicprivate partnership. Source: compiled by the authors on the basis of materials (Petrov, 2015, Petrov, 2016).

The investor invests its funds in the form of long-term investments in the project and (or) attracts long-term loans from banks. At the same time, there are three possible options for implementing the project: 1) direct purchase of equipment, livestock and construction financing at the expense of the investor's own funds; 2) attracting long-term bank loans for this purpose; 3) use of the leasing mechanism. Accordingly, when implementing the project, different options are possible for combining these three sources of funds.

The credit organization provides a target loan for the implementation of the project (long-term) and short-term loans for the agricultural organization to strengthen the production capacity. The borrower of long-term credit is the investor, but since the loan is targeted for the implementation of the agricultural project, the state subsidizes part of the interest on the loan in accordance with the point of the state target program. Repayment of the loan and payment of interest (other than the subsidized part) will be carried out at the expense of income from the sale of products (milk). The investor acts only as a guarantor of credit repayment and interest payments. 
The leasing company supplies the equipment and (or) the breeding cattle in leasing. In this case, the investor pays the initial fee. Payment of current leasing payments will be carried out at the cost price of production. Using a leasing mechanism allows minimizing the financial burden on the investor.

The processing organization concludes a long-term contract with the agricultural organization for the purchase of milk produced according to the project being implemented. Hence, the sale will be guaranteed and the selling price established which will give stability to the project and confidence to the investor. The main interest of the processing enterprise is the growth in the supply of milk for processing, and accordingly the income from the production and sale of dairy products.

Scientific research institutions perform several functions as the project progresses. Firstly, they carry out an examination and a scientific justification for the project, an examination of the business plan. Secondly, they adjust the project and adapt it to local conditions. Thirdly, they train and retrain the personnel of the agricultural organization to use the latest equipment and modern technologies. These services are paid primarily from the state budget (including the budget of the employment fund).

Involvement of scientific and educational institutions in the project will reduce the risk of the project implementation, as additional scientific examination and adjustment of the project will be carried out. Scientific institutions in turn will be connected with real production.

The state authorities (of all levels) participate in attracting investors for the implementation of the project, provide support and create the most favorable conditions primarily by simplifying administrative procedures, co-finance and subsidize the project in the amounts provided for by the federal and regional programs. The main task for working with investors lies on the regional authorities, as local authorities do not have enough resources for this, and the federal authorities are too far from small enough projects. The interest of regional and local authorities is in the development of production, increasing employment and tax revenues.

The sequence of the project implementation will be as follows:

1. Regional authorities shall adopt and publish rules and conditions for the implementation of the investment project on the basis of public-private partnership.

2. An agricultural organization wishing to take part in the implementation of the investment project on its base, submits an application for participation to the regional authority.

3. A research institution carries out the analysis of the project and, in cooperation with the agricultural organization, prepares a business plan for the investment project.

4. Regional authorities start looking for an investor for the investment project, submitting the business plan for consideration to potential investors.

5. When an investor ready to invest in a project, appears, the plan is adjusted to the conditions of the particular investor, and the investment agreement is concluded.

As an example, let us consider the project for the construction of a dairy farm with a population of the main herd of 400-head dairy cows. It is not advisable to consider a project with a smaller number of livestock, since with a smaller number of cows, production will be less effective, and development will be less sustainable. The productivity is set at 6000 $\mathrm{kg}$ per head per year. The project envisages the acquisition of only breeding cattle with high productivity. Without this, investments will not be advisable, as they will not pay off or the payback period will be prolonged.

The volume of capital investments, calculated on the basis of actual investments in agricultural organizations of the Ulyanovsk region, is 110 million rubles (275 thousand rubles per $1 \mathrm{cow}$ ), including 57 million rubles for the construction of buildings and structures, 19 million rubles for the purchase of equipment and 34 million rubles for the 
purchase of breeding stock. A few agricultural organizations will be able to make such large investments at their own expense or independently raise funds in the form of longterm investments.

Of the 110 million ruble, the investor's share is 94 million rubles, and 16 million rubles is the state compensation of costs for the purchase of equipment and breeding cattle in accordance with the state program.

The project is calculated for a long-term perspective (for 13 years). The inflation rate equal to $6 \%$ is applied to the cost indicators (for wages it will be 10\%). As the initial price of milk sales, the price of 2016 for agricultural organizations with a livestock of 400 to 600 cows is taken with an annual increase of $6 \%$, which is $1 \%$ less than the actual increase in the milk procurement prices for 2011-2016. The result of the calculation of the profitability of milk production at a dairy farm under the investment project is shown in the Table 1.

Table 1. The main parameters of the development of dairy cattle breeding under the investment project.

\begin{tabular}{|c|c|c|c|c|c|c|c|c|c|c|}
\hline 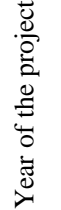 & $\begin{array}{c}\text { Size of } \\
\text { investments } \\
\text { thousand } \\
\text { rubles }\end{array}$ & $\begin{array}{l}\text { Including } \\
\text { state } \\
\text { subsidies, } \\
\text { thousand } \\
\text { rubles }\end{array}$ & $\begin{array}{l}\text { Number } \\
\text { of cows }\end{array}$ & $\begin{array}{c}\text { Annual } \\
\text { productivity, } \\
\mathrm{kg} .\end{array}$ & $\begin{array}{c}\text { Gross } \\
\text { yield, } \\
\text { centner }\end{array}$ & $\begin{array}{l}\text { Milk } \\
\text { sales, } \\
\text { centner }\end{array}$ & $\begin{array}{l}\text { Cost price } \\
\text { of } 1 \text { centner } \\
\text { of milk, } \\
\text { rubles }\end{array}$ & $\begin{array}{c}\text { Selling } \\
\text { price of } \\
1 \\
\text { centner } \\
\text { of milk, } \\
\text { rubles }\end{array}$ & $\begin{array}{c}\text { Level of } \\
\text { profitabil } \\
\text { ity, } \%\end{array}$ & $\begin{array}{l}\text { Net cash } \\
\text { flow, } \\
\text { thousand } \\
\text { rubles }\end{array}$ \\
\hline $1 \mathrm{st}$ & 110000 & 16000 & 400 & - & - & - & - & - & - & - \\
\hline 2nd & - & - & 400 & 5000 & 20000 & 18080 & 1722.9 & 1876.2 & 8.9 & -97410 \\
\hline $3 \mathrm{rd}$ & - & - & 400 & 5500 & 22000 & 20080 & 1654.8 & 1988.8 & 20.2 & -83269 \\
\hline 4th & - & - & 440 & 6000 & 26400 & 24288 & 1539.2 & 2108.1 & 37.0 & -65172 \\
\hline 5 th & - & - & 480 & 6000 & 28800 & 26496 & 1565.3 & 2234.6 & 42.8 & -40286 \\
\hline 6 th & - & - & 524 & 6000 & 31440 & 28925 & 1597.2 & 2368.7 & 48.3 & -11885 \\
\hline 7 th & - & - & 572 & 6000 & 34320 & 31574 & 1692.9 & 2510.8 & 48.3 & 20556 \\
\hline 8 th & - & - & 600 & 6000 & 36000 & 33120 & 1794.1 & 2661.4 & 48.3 & 55230 \\
\hline 9th & - & - & 600 & 6000 & 36000 & 33120 & 1910.7 & 2821.1 & 47.6 & 95427 \\
\hline 10th & - & - & 600 & 6000 & 36000 & 33120 & 2034.9 & 2990.4 & 470 & 137582 \\
\hline 11th & - & - & 600 & 6000 & 36000 & 33120 & 2167.2 & 3169.8 & 463 & 181762 \\
\hline 12th & - & - & 600 & 6000 & 36000 & 33120 & 2308.0 & 3360.0 & 45.6 & 228045 \\
\hline 13th & - & - & 600 & 6000 & 36000 & 33120 & 2458.0 & 3561.6 & 44.9 & 276511 \\
\hline
\end{tabular}

Source: calculated by the authors on the basis of materials (A.A. Petrov, 2015, Petrov, 2016).

Thus, according to the calculations, a stable and efficient dairy production, capable of independent development will be obtained as a result of the investment project implementation. An important condition for successful activity is the possibility of independent extended reproduction of the main herd. The production turns out to be profitable and payback. The investments in the project will pay off on the seventh year.

In the course of the project, the investor will receive income in two forms: return of investment through transferring depreciation on fixed capital of the dairy farm and a percentage of the invested capital in the form of a part of the profit from the sale of milk. To quickly return the funds invested, it is proposed to use accelerated depreciation. This will allow the investor to return the invested funds faster, and the agricultural organization will get the depreciated but still usable fixed assets under its full control.

Table 2. Evaluation of the return on investment in the construction of a dairy farm. 


\begin{tabular}{|c|c|c|c|c|c|c|c|}
\hline \multirow{2}{*}{\begin{tabular}{|} 
Year of \\
the project
\end{tabular}} & \multirow{2}{*}{$\begin{array}{c}\text { The size of } \\
\text { the } \\
\text { investor's } \\
\text { capital, } \\
\text { thousand } \\
\text { rubles } \\
\end{array}$} & \multirow{2}{*}{$\begin{array}{l}\text { Current } \\
\text { costs, } \\
\text { thousand } \\
\text { rubles. }\end{array}$} & \multirow{2}{*}{$\begin{array}{c}\text { Depreciation, } \\
\text { thousand } \\
\text { rubles }\end{array}$} & \multicolumn{3}{|c|}{ Profit for distribution, thousand rubles } & \multirow{2}{*}{$\begin{array}{c}\text { Profitability } \\
\text { of } \\
\text { investments, } \%\end{array}$} \\
\hline & & & & Total & $\begin{array}{c}\text { To } \\
\text { investor }\end{array}$ & $\begin{array}{c}\text { To agricultural } \\
\text { organization }\end{array}$ & \\
\hline $1 \mathrm{st}$ & 94000 & 7149 & 2541 & - & - & - & - \\
\hline 2nd & 91459 & 31055 & 7624 & 2771 & 2069 & 702 & 2.3 \\
\hline 3rd & 83835 & 33299 & 7624 & 6706 & 4800 & 1906 & 5.7 \\
\hline 4th & 76211 & 38190 & 7624 & 13816 & 9204 & 4612 & 12.1 \\
\hline 5 th & 68587 & 43136 & 7624 & 17733 & 10886 & 6847 & 15.9 \\
\hline 6 th & 60963 & 48923 & 7624 & 22316 & 12380 & 9935 & 20.3 \\
\hline 7th & 53339 & 51858 & 7624 & 23654 & 11994 & 11661 & 22.5 \\
\hline 8 th & 45715 & 54969 & 7624 & 25074 & 11385 & 13689 & 24.9 \\
\hline 9th & 38091 & 58268 & 7624 & 26578 & 10506 & 16072 & 27.6 \\
\hline 10th & 30467 & 61764 & 7624 & 28173 & 9306 & 18866 & 30.5 \\
\hline 11 th & 22843 & 65469 & 7624 & 29863 & 7724 & 22139 & 33.8 \\
\hline 12th & 15219 & 69398 & 7624 & 31655 & 5693 & 25962 & 37.4 \\
\hline 13th & 7595 & 73562 & 7624 & 33554 & 3140 & 30414 & 41.3 \\
\hline
\end{tabular}

Source: calculated by the authors on the basis of materials (A.A. Petrov, 2016).

The distribution of profits can become the most difficult task as referred to the project participants, namely the private investor and the agricultural commodity producer. It is supposed, in full accordance with the theory of K. Marx, to distribute it proportionally to labor and capital invested in the production. That is, the part of the profit attributable to distribution for each party will be proportional to the share in the total amount of labor invested (in the form of wages), fixed capital (in the form of investment minus the accrued depreciation) and consumed working capital (in the form of current material costs). At the beginning of the project, the investors' share may be significantly higher than the share of the agricultural commodity producer. But as they return their investments in the form of obtaining depreciation charges, their share in profits will decrease, and the share of the agricultural organization will accordingly grow. This is confirmed by the calculations in the Table 2.

Until the time of full compensation of the value of the capital invested to the investor, the equipment and breeding livestock purchased for its investment serve as a guarantee for the investor's property interests. Also an additional guarantee is the condition of compulsory insurance of the property purchased for the project.

The size of the investor's capital in the project is gradually decreasing, and its share in the profit from sales decreases. The investor will be able to completely return the invested funds and exit the project on the $13^{\text {th }}$ year. The average annual value of interest on the invested capital for this time will be $14.4 \%$, and taking into account the discounting $11.8 \%$. This value is small, but it exceeds the rates of inflation in recent years (and projected for the near future), as well as the refinancing rate of the Central Bank of Russia. That is, the investor can get real (and not only nominal) income and improve its reputation in the eyes of the population, as well as regional and federal government bodies.

The agricultural enterprise receives "turnkey" efficient and cost-effective production, first in management, and then in ownership. The state power will receive one more successful production, and the society will have the increased supply of locally produced milk and new jobs. 
To increase milk production in accordance with the target value laid down in the regional state program, it is necessary to realize about 29 such investment projects until 2020 , provided milk production in the households and the production growth dynamics in the peasant farm are maintained. The work on attracting private investors to dairy production will be one of the directions of the state support of the industry.

\section{Conclusion}

To implement the target indicators of the regional state program in the Ulyanovsk region, it is expedient to implement investment projects in dairy cattle breeding using the mechanism of public-private partnership. Participation in the project of many different organizations and the distribution of roles between them is aimed at reducing and distributing risks. The planned profitability can make dairy cattle breeding attractive for investments.

\section{References}

1. HM Treasure, A new approach to public private partnerships (HM Treasure, London, 2012)

2. M. L. Lawson, Foreign assistance: public-private partnerships (PPPs) (Congressional Research Center, Washington, 2013)

3. P. Brusser, S. Rozhkova, Stocks and Bonds Market, 2 (2007)

4. D. Delmon, Public-private partnership in infrastructure: practical guidance for public authorities (World Bank, Washibgton, 2010)

5. E. V. Zusman, K. M. Arakelyan, Etap: Economic Theory, Analysis, Practice, 4 (2010)

6. A. E. Zyatkov, Izvestiya RSPU named after A. I. Herzen, 86 (2008)

7. I. N. Kvasov, Vestnik PGU - Series: Economics, 2 (2010)

8. M. Kozlov, V. Letov, AIC: Economics, Management, 12 (2012)

9. T. I. Kubasova, Izvestia IGEA, 4 (2009)

10. E. N. Kuznetsov, Fundamental and Applied Research of the Cooperative Sector of the Eeconomy, 5 (2010)

11. A. Yu. Kulikov, Bulletin of the Samara State University - Series: Economics, 10 (2012)

12. A. R. Kulov, Economics of Agricultural and Processing Industries, 10 (2011)

13. E. A. Makhortov, A. S. Semchenkov, Bulletin of Moscow University - Series 12: Political Science, 6 (2007)

14. A. A. Petrov, Public-private partnership: state and problems (Nauka-Plus, Makhachkala, 2015)

15. A. A. Peteov, Almanac of Modern Science and Education, 12 (2016)

16. V. S. Pilyakina, Modern Economics: Problems and Solutions, 4 (2010)

17. E. B. Plotnikova, Bulletin of the Tomsk State University, 1 (2011)

18. A. Ya. Porovskaya, Bulletin of the Tomsk State University, 328 (2009)

19. A. Ya. Porovskaya, Bulletin of the Tomsk State University, 312 (2008)

20. I. S. Sandu, N. E. Ryzhenkova, Materials of the III All-Russian scientific and practical conference on regional problems of small agribusiness (PSAA, Penza, 2015) 
21. CI. V. Sycheva, Bulletin of the Tula State University - Economic Sciences and Law, 2, 2 (2010)

22. I. V. Sycheva, N. A, Sychev, Bulletin of the Tula State University - Economic Sciences and Law, 2, 1 (2013)

23. Chamber of Commerce and Industry of the Russian Federation, Public private partnership (CCIRF, Moscow, 2016)

24. I. G. Ushachev, I. S. Sandu, G. M. Demishkevich, R. V. Ilyukhina, G. S. Prokopyev, Formation of the innovative system of the agroindustrial complex: the mechanism of public-private partnership (ARSRIEA, Moscow, 2014)

25. N. D. Kholodnaya, Questions of State and Municipal Governance, 2 (2009) 